However, it is evident that a strategic plan that even begins to deal with the tough questions cannot be written by researchers at regional meetings. Once the current exercise in participatory democracy is concluded, (four meetings open to the research community at large are scheduled for the next few weeks), Healy should bring the effort back to NIH, but not to closed meetings of institute directors. Rather, strategic planning should be handed over in its next phase to the institute councils, particularly the one that advises the director. If the hard questions can be framed and openly debated, strategic planning will have served a useful purpose. If researchers can, by laying out priorities, convince Congress to spend more on biomedical research, so much the better. But it will all be for naught unless the research community is willing to put its mind to the task of making choices.

\section{Swiss conundrums}

Next Sunday's referendum on animals in research could damage Swiss research, academic and industrial.

SwITZERLAND, by European standards one of the most rational, cultivated and prosperous of states, appears to be on the brink of an uncharacteristic act of waywardness. In Sunday's referendum, the population will be asked to declare itself for or against the use of animals in research (see page 575). But not in as many words. Those who have devised the proposition have cleverly cloaked their intentions in a show of reasonableness: research using animal experiments will continue to be allowed if it can be shown to benefit directly the welfare of people or other animals. What, puzzled voters will be asking on Sunday, can be wrong with that?

Several things. If passed on Sunday and then literally translated by the federal government into legislation, Sunday's proposition will be the death of much academic research. What, for example, if researchers wishing to make antibodies against proteins involved in gene regulation confess their need to use mice or rabbits in the process? They may argue that a better understanding of gene regulation will eventually benefit the practice of medicine, but that benefit will hardly be direct. Alternatively, they may persuade collaborators or commercial laboratories outside Switzerland to make their antibodies in return for some appropriate consideration. But many researchers, faced with such a prospect, will prefer to work in some other field or to emigrate from even Switzerland's lush pastures. Is such an impoverishment of Switzerland's research enterprise what the people really intend?

One paradox is that Switzerland already enjoys some of the most careful legislation on the use of animals in research. And, given the noise that animal welfare groups have been making, the enforcement of the legislation has become noticeably tighter in the past few years, to the point at which research group leaders at commercial laboratories are now accustomed to telephone invigilation by animal welfare supervisors at Berne, the federal capital. To the extent that researchers are thereby vividly reminded of their responsibilities, few can complain, but over-zealous regulation can be as serious an impediment to research as over-intrusive legislation.

Another, and more puzzling, paradox is that much of Switzerland's wealth derives from a handful of successful multinational pharmaceutical manufacturers, whose indigenous research can only be hampered if Sunday's proposition gives animal welfare groups the right to challenge in the courts experimental protocols involving animals. Although most research related to the development of drugs is relevant to human welfare, the pharmaceutical companies rightly fear the nuisance likely to be licensed by legislation if the proposition is accepted. For the rest of us, it is already remarkable that Swiss environmentalists, from their stronghold in the canton of Basle, have fallen into an antagonistic relationship with their most successful industry. To give them a licence to go further will be yet another proof that only the very rich can afford to indulge in such self-impoverishment.

\section{Patron of science}

Jack Whitehead, wealthy from success in technology, gave his energy and resources to pure science.

EDWIN C. (Jack) Whitehead died on 2 February at the age of 72 . He was playing squash. Whitehead, an energetic, feisty, and persistent man of great wealth, is best known as the founder of the Whitehead Institute at the Massachusetts Institute of Technology. Now a decade old and well established as a centre of intellectual power in molecular biology (and until recently headed by his friend David Baltimore), the institute is testament to Whitehead's belief that real advances in medicine and biotechnology derive from research into the structure and mechanisms of living things. Although his wife, Elizabeth Jones, to whom the library at the institute is dedicated, died of breast cancer, Whitehead was never lured by the idea that disease can be cured by targeted research.

But, his desire to create an institute for basic science took years to fulfil. More than one medical school declined Whitehead funds on grounds that there were too many strings attached, leading him to comment that "it is easier to make $\$ 100$-million than to give it away".

Whitehead, who made his considerable fortune from Technicon, a company he and his father started in 1939 that marketed the first blood autoanalysers to medical and research laboratories, did not put all his energies into the Whitehead Institute. Particularly after he sold Technicon to Revlon for \$400-million in May 1980, he channelled much of his attention to the US National Library of Medicine, where he headed a group of prominent citizens dedicated to the library's support, and to a fledgling organization called Research! America whose mission is to teach the US Congress and public alike that the treatment and cure of disease lies in basic research.

Whitehead should be remembered as one of this century's most important patrons of pure science, of whom there are entirely too few. 